薬

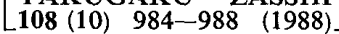

\title{
ブタ腎臓抽出液のコロニー増幅活性について
}

柏倉幾郎, 早瀬幸俊, 高木良成*

北海道薬科大学

\section{Colony Promoting Activity in Porcine Kidney Extract}

\author{
Ikuo Kashiwakura, Yukitoshi Hayase, and Yoshinari Takagi* \\ Hokkaido Institute of Pharmaceutical Sciences, 7-1, \\ Katsuraokacho, Otaru, 047-02, Japan
}

(Received April 22, 1988)

\begin{abstract}
Aqueous extracts prepared from porcine kidneys (PKE) were found to promote colony formation in agar cultures of mouse bone marrow cells stimulated by colony stimulating factor (CSF) and to exhibit no detectable activity of CSF. The extract (PKE) enhanced colony formation about twice in comparison with control. On the cultures of the marrow cells from 5-FU injected mice with PKE, colony enhancement ratio increased to 3 and 1.5 times in comparison with that of control and that of 5-FU untreated mice, respectively. Futhermore, preincubation of bone marrow cells with PKE for 2 or $3 \mathrm{~d}$ caused an increase in the number of colony forming units in culture (CFU-C) by a factor of 1.5 of its initial number, whereas preincubation without PKE caused a considerable decrease of CFU-C number.

These results suggest that the colony promoting activity of PKE influenced colony growth by enhancing the target cells of CSF. And there is a possibility that the colony promoting activity of PKE is a physiological factor in maintaining the number of CSFresponsive cells by proliferating and differentiating pre-CFU-C.

It is found that there is a similarity between the colony promoting activity of PKE and the other sources in regard to heat sensitivity, trypsin sensitivity and some properties of their target cells.
\end{abstract}

Keywords - colony promoting activity; CFU-C (colony forming unit in culture); kidney; kidney extract; bone marrow culture

白血球系幹細胞 (colony forming unit in culture, CFU-C) が增殖分化し軟寒天培養系でコロニーを形成する ためには, colony stimulating factor (CSF) の存在を必要とする. ${ }^{1,2)} \mathrm{CSF}$ は血清, ${ }^{8)}$ 人尿, ${ }^{4)}$ 組織抽出物 ${ }^{5)}$ 又は 種々の細胞や組織の培養液-9)に含まれることが知られている. 更に CSF 活性を持たないが，CSF と共存させ ることによりコロニー数を増加させる因子 (colony promoting activity, CPA) が存在することが知られている. CPA は, 赤血球の溶血液 ${ }^{10)}$ や細菌内毒素を投与したマウスの血清, ${ }^{11)}$ マウ 骨䭫細胞の長期培養上清13,14) 中に見い出されて扮り，その作用は CFU-C より未成熟な前駆細胞 (pre-CFU-C) に作用し，pre-CFU-C CSF 反応性の CFU-C 飞まで增殖分化させると推定されている. 近年, Aizawa ら は CPA を含むマウス骨䯣性白血病細胞培養上清を CSF と共にマウスに静脈内投与した結果, 末梢血中の顆粒 球数及び脾臟中の colony forming unit in spleen (CFU-S), CFU-C の数が增加することを報告しており，CPA が in vivoでも造血作用をもつことが示唆された.

著者らは,ブタ腎臓の可溶性分画中に CPA が存在することを認め，その作用及び性質について検討した。

\section{実 験 方 法}

ブタ腎臓抽出液 (PKE) の調製 屠殺後 3 時間以内のブタ腎臟を使用した. 氷冷下で蒸留水を加兄, Waringblendor により $12 \%(\mathrm{w} / \mathrm{v})$ ホモジネートを作成した。このホモジネートを $1 \times 10^{5} \mathrm{~g}$ (Hitachi rotor $42 \mathrm{~T}, 37500$ $\mathrm{rpm}, 4^{\circ} \mathrm{C}, 30 \mathrm{~min}$ ) で遠心分離し, 得られた上澄を凍結乾燥した。これをもとの超遠沈上澄液量の $1 / 10$ 容量の䓠 
留水に溶解後, 硫安分画を行い, $50 \%$ 以上 $65 \%$ 飽和画分を採取した。これを 100 倍量の蒸留水に対しVisking チューブを用いて 3 回透析した後涷結乾燥し, 超遠沈上澄液量の $1 / 50$ 容量の蒸留水に溶解後, メンブランフィ

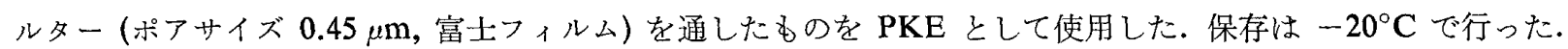
実験には同一ロットのものを使用した.

CPA の測定 Tsurusawa ら ${ }^{14)}$ の方法に基づき, 軟寒天コロニー形成法により行った. CSFとしてマウス腹 膜培養液 20\%，ウマ血清 (Gibco) 20\%，寒天（Difco） 0.32\% 及び ddY 系成熟雄性マウス大腿骨より得た骨䯣 細胞 $5 \times 10^{4}$ 個を含を F-10 培地と PKE の混合液 $1 \mathrm{ml}$ を, 直径 $35 \mathrm{~mm}$ のプラスチックシャーレ (テルモ) ルま き, $37^{\circ} \mathrm{C}, 5 \% \mathrm{CO}_{2}$ 存在下で 7 日間培養した後, 細胞 50 個以上からなるコロニーを計数した.

骨髄細胞の Preincubation マウス大腿骨より得た骨髄細胞を，PKE $0.5 \mathrm{ml}$, ウマ血清 20\%を含むF-10 培 地 $10 \mathrm{ml}$ に, 細胞濃度が $8-9 \times 10^{5}$ cells $/ \mathrm{ml}$ になるように浮遊させ, $37^{\circ} \mathrm{C}, 5 \% \mathrm{CO}_{2}$ 存在下で 1 一 incubate した. PKE の代わりに蒸留水を加えたものを対照とした. 次に, 細胞を F-10で 3 回洗浄し適当量の F-10 に懸濁して細胞数を計数した後, CSF としてマウス腹膜培盖液を含さ軟寒天培養系で 7 日間培養し, コ口 ニ一数を計数した.

CSF の調製 $\quad$ 1) 腹膜 CSF (マウス腹膜培養液, AWCM): ddY 系成熟雄性マウスより腹膜を無菌的に取り 出し,リン酸緩衝生理食塩水で洗浄した後細切し, ウマ血清 $20 \%$ を含む F-10 培地 $10 \mathrm{ml}$ に浮遊させ, $37^{\circ} \mathrm{C}$, $5 \% \mathrm{CO}_{2}$ 存在下で培養した. 3 日後培養液を回収し, 減菌沪過し, 使用するおで $-20^{\circ} \mathrm{C} て ゙$ 保存した. 2) ADCM: 前に報告したマウス骨髄細胞長期培養由来の吸着細胞が産生する CSF (adherent cell conditioned medium, $\mathrm{ADCM})^{18)}$ を用いた。長期培養細胞を 10\% fetal calf serum (FCS) を含む F-10 培地で培養し, confluentに 達した後 serum-free F-10 培地に替え, 更に 4 日間培養した。得られた無血清培養液を限外汇過（PM-10， ADVANTEC) により濃縮し，使用するまでー $20^{\circ} \mathrm{C}$ で保存した。

トリプシン処理 試料 $0.2 \mathrm{ml}$ (蛋白濃度 $6 \mathrm{mg} / \mathrm{ml}$ ) に対し, $4 \mathrm{mg} / \mathrm{ml}$ の trypsin (bovine pancreas, Sigma)

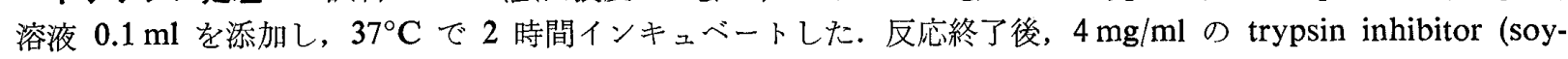
beans, Sigma) 溶液 $0.1 \mathrm{ml}$ を添加し, 更に 30 分間インキュベート後 $100 \mu 1$ あたりのCPA を測定した. 別に

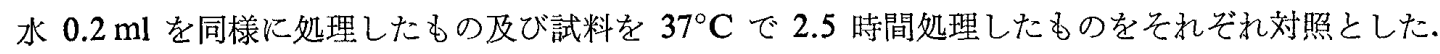

コロニー構成細胞種の判定＼cjkstart既報のエステラーゼ 2 重染色法 ${ }^{172 を}$ 適用した. 培養終了後, 軟寒天層をスライ ドグラス上に移し取り，冷風で乾燥後，10\% ホルマリンーメタノール溶液で固定した．非特異的エステラーゼ染 色は，基質に $\alpha$-naphthyl butyrate (Sigma)，色素に fast garnet GBC salt (Sigma) を用い，またクロロアセテー トエステラーゼ染色の場合にはそれぞれ naphthyl AS-D chroloacetate, fast blue GBC salt (いずれも Sigma) を用いた。後染色は，Mayer のへマトキシリン染色で行った。

5-Fluorouracil (5-FU) 投与マウス骨䯣細胞の調製Ｓuda ら ${ }^{18)}$ の方法を参考に行った. 生後 10 週齢の BDF $_{1}$ 雌マウスに対し，5-FU (協和発酵) を尾静脈投与 $(120 \mathrm{mg} / \mathrm{kg}$ of body weight) し，4 日後に大腿骨より咀骨道細胞 を採取し使用した。

結果

\section{コロニー数に対する PKE の影響}

一定量の CSF 存在下で PKE の添加量の変化に伴らコロニー数の変化を検討した. Table I に示すよらに, PKE の添加量を 5-100 $\mu 1$ と増加させるに伴いCSF 単独に比べ 1.49-2.23 倍のコロニー数の増加が認められ た.CSFを加えない状態ではPKEを $100 \mu \mathrm{l}$ まで増加させてもコロニー形成は認められず，CSFは検出されな かった。な拉，いくつかの PKE のロットについても CPA の測定を行ったが，いずれのロットにも同程度の活 性が検出された。

\section{PKE の作用に及ぼす CSF 濃度の影響}

PKE $50 \mu$ 存在下で, CSF (AWCM) の添加量を 0\%-20\% をで変え, コロニー数を測定した. CSF 単独では CSF 量の増加に伴いコロニー数も増加し $15 \%$ で最大刺激濃度に達した。これに対してPKEを添加した時には 各 CSF 濃度で 2-2.7 倍のコロニー数の増加がみられたが, Table II に示すよらにほぼ最大刺激を示すCSF 量 に拉いては PKE の増幅活性に大きな差は認められなかった。

\section{コロニー組成に及ぼす PKE の影響}

2 種類の性質の異なった CSF について，コロニー組成に対する PKE の影響を検討した (Table III). いずれ の CSF も最大刺激濃度で行った，AWCM を用いた場合，顆粒球コロニーが $73 \%$ と最も多く形成されるが， 
TABLE I. CPA of PKE

\begin{tabular}{rrrr}
\hline \multirow{4}{*}{$\begin{array}{c}\text { PKE } \\
\mu \mathrm{I})\end{array}$} & \multicolumn{2}{c}{$\begin{array}{c}\text { No. of colonies/ } \\
5 \times 10^{4} \text { bone marrow cells }\end{array}$} & \\
\cline { 2 - 3 } Ratio $\left.^{b}\right)$ & $\begin{array}{c}\text { Without } \\
\text { CSF }\end{array}$ & $\begin{array}{c}\text { With } \\
\left.\text { CSF }^{a}\right)\end{array}$ & \\
\hline 0 & 0 & $51.2 \pm 4.1$ & 1.00 \\
5 & 0 & $76.5 \pm 3.5$ & 1.49 \\
10 & 0 & $83.9 \pm 4.4$ & 1.64 \\
20 & 0 & $94.5 \pm 5.9$ & 1.85 \\
50 & 0 & $106.5 \pm 4.7$ & 2.08 \\
100 & 0 & $114.2 \pm 9.2$ & 2.23 \\
\hline
\end{tabular}

Mean \pm S.E. of 6 dishes from two separate experiments. a) CSF: mouse abdominal wall conditioned medium. (AWCM) $20 \%$ b) Ratio: with PKE/without PKE.
TABLE II. Effect of CSF Concentration on CPA of PKE

\begin{tabular}{cccc}
\hline & \multicolumn{2}{c}{$\begin{array}{c}\text { No. of colonies/ } \\
\text { CSF } \\
(\%)\end{array}$} & \multicolumn{2}{c}{$5 \times 10^{4}$ bone marrow cells } & \\
\cline { 2 - 3 } & $\begin{array}{c}\text { Without } \\
\text { PKE }\end{array}$ & $\begin{array}{c}\text { With } \\
\text { PKE }^{b)}\end{array}$ & \\
\hline 0 & 0 & 0 & \\
& $31.7 \pm 0.7$ & $87.0 \pm 7.6$ & 2.74 \\
5 & $39.4 \pm 2.8$ & $99.7 \pm 5.3$ & 2.02 \\
10 & 49.4 & 2.05 \\
15 & $53.2 \pm 5.5$ & $109.2 \pm 8.7$ & 2.08 \\
20 & $51.9 \pm 4.7$ & $107.9 \pm 4.7$ & 2.7 \\
\hline
\end{tabular}

Mean \pm S.E. of 6 dishes from two separate experiments. a) CSF: mouse abdominal wall conditioned medium. (AWCM). b) $50 \mu 1 /$ dish. c) Ratio: with PKE/without PKE.

TABle III. Effect of PKE on Colony Type

\begin{tabular}{|c|c|c|c|c|}
\hline & No. of colonies & Macropharge & Mixed & Granulocyte \\
\hline AWCM & $\begin{array}{c}51.1 \pm 3.4 \\
(100 \%)\end{array}$ & $\begin{array}{l}5.5 \pm 0.5 \\
(10.8 \%)\end{array}$ & $\begin{array}{r}8.1 \pm 0.6 \\
(15.9 \%)\end{array}$ & $\begin{array}{c}37.5 \pm 3.7 \\
(73.2 \%)\end{array}$ \\
\hline AWCM+PKE & $\begin{array}{c}107.2 \pm 3.2 \\
(100 \%)\end{array}$ & $\begin{array}{c}11.1 \pm 0.9 \\
(10.4 \%)\end{array}$ & $\begin{array}{r}23.5 \pm 1.5 \\
(21.9 \%)\end{array}$ & $\begin{array}{c}72.6 \pm 3.6 \\
(67.7 \%)\end{array}$ \\
\hline Ratio & 2.1 & 2.0 & 2.9 & 2.0 \\
\hline ADCM & $\begin{array}{c}40.7 \pm 0.9 \\
(100 \%)\end{array}$ & $\begin{array}{r}40.7 \pm 0.9 \\
(100 \%)\end{array}$ & 0 & 0 \\
\hline $\mathrm{ADCM}+\mathrm{PKE}$ & $\begin{array}{c}80.7 \pm 9.1 \\
(100 \%)\end{array}$ & $\begin{array}{r}80.7 \pm 9.1 \\
(100 \%)\end{array}$ & 0 & 0 \\
\hline Ratio & 2.0 & 2.0 & - & - \\
\hline
\end{tabular}

Mean \pm S.E. of 6 dishes from two separate experiments.

PKE の添加によってもその組成に大きな変化は認められなかった。一方, ADCM では形成されるのはすべてマ クロファージュロニーであり, PKE の添加でコロニー数は増加したが, すべてマクロファージュロニーであっ た.したがって、コロニ一組成に対するPKE の影響はほとんぞ認められなかった。

\section{PKE の安定性}

Table IV に示したように，未処理のPKE の添加により、コロニ一数は対照の 2.2 倍に増加するのに対し， $56^{\circ} \mathrm{C}$ で 30 分間又は 60 分間加熱処理した PKE でのコロニー数の増加は, いずれの場合も 1.4 倍, $70^{\circ} \mathrm{C}, 30$ 分 間加熱処理した PKE では 1.1 倍となり，コロニー増幅活性は熱に対し不安定であることが明らかとなった。一 方,トリプシン処理した PKE では Table V に示すように，コロニー数の増加は認められず, コロニー増幅活 性はトリプシン感受性であることも明らかとなった。

\section{Preincubation における骨檤細胞に対する PKE の影響}

骨髄細胞を 20\% ウマ血清を含む F-10 培地に浮遊させ，1-3 日間 PKE と preincubate した後, 細胞を洗浄 し，CSF を加壳て軟寒天培養を行った (Table VI). PKE の有無にかかわらず総細胞数は同程度に減少したが， preincubation 時に PKE を添加したものでは,フラスコあたりの CFU-C 数は開始時に比べて 1 日目で 105\%， 2 日目及び 3 日目で約 150\% に增加した。 これに対して, PKE を添加しなかったるのでは CFU-C 数は日を 追って減少し， 3 日目には開始時の $12.7 \%$ 飞減少した。 また骨䯣細胞 $1 \times 10^{4}$ 個あたりのコロニー数すなわち CFU-C の濃度は，PKE を添加しない場合には開始時と顕著な差は認められなかったが，PKE を添加した場合 には日を追って増加し, 3 日目では開始時の約 16 倍に増加した。 
TABLE IV. Effect of Heating on CPA of PKE

\begin{tabular}{lcc}
\hline \multicolumn{1}{c}{ Treatment } & No. of colonies & Ratio \\
\hline Control & $56.7 \pm 1.1$ & 1.00 \\
Untreated PKE & $125.7 \pm 3.8$ & 2.22 \\
$56^{\circ} \mathrm{C}, 30 \mathrm{~min}$ PKE & $79.4 \pm 4.9$ & 1.40 \\
$56^{\circ} \mathrm{C}, 60 \mathrm{~min} \mathrm{PKE}$ & $78.8 \pm 2.3$ & 1.39 \\
$70^{\circ} \mathrm{C}, 30 \mathrm{~min} \mathrm{PKE}$ & $63.3 \pm 3.2$ & 1.12 \\
\hline
\end{tabular}

Mean \pm S.E. of 6 dishes from two separate experiments.
TABLE V. Effect of Trypsin Digestion on CPA of PKE

\begin{tabular}{lrr}
\hline \multicolumn{1}{c}{ Treatment } & No. of colonies & Ratio \\
\hline Control & $48.7 \pm 2.4$ & 1.00 \\
$37^{\circ} \mathrm{C}, 2.5 \mathrm{~h}$ PKE & $106.3 \pm 0.7$ & 2.18 \\
Trypsinized PKE & $50.0 \pm 2.5$ & 1.03 \\
\hline
\end{tabular}

Mean \pm S.E. of 6 dishes from two separate experiments.

TABLE VI, Effect of Preincubation of Bone Marrow Cell with PKE on CFU-C

\begin{tabular}{|c|c|c|c|c|c|c|}
\hline \multirow{2}{*}{$\begin{array}{l}\text { Incubation } \\
\text { time } \\
\text { (d) }\end{array}$} & \multicolumn{2}{|c|}{ No. of cells $\left(\times 10^{-4}\right)$} & \multicolumn{2}{|c|}{ Colonies $/ 10^{4}$ cells } & \multicolumn{2}{|c|}{ No. of $\underset{\text { flask }}{\text { CFU-C }}\left(\times 10^{-3}\right) /$} \\
\hline & $\operatorname{PKE}(-)$ & PKE (+) & $\operatorname{PKE}(-)$ & $\operatorname{PKE}(+)$ & PKE (-) & PKE (+) \\
\hline 0 & \multicolumn{2}{|c|}{$\begin{array}{c}873 \\
(100 \%)\end{array}$} & \multicolumn{2}{|c|}{15.4} & \multicolumn{2}{|c|}{$\begin{array}{c}13.4 \\
(100 \%)\end{array}$} \\
\hline 1 & $\begin{array}{c}232 \\
(26.6 \%)\end{array}$ & $\begin{array}{c}238 \\
(27.3 \%)\end{array}$ & 26.4 & 59.4 & $\begin{array}{c}6.1 \\
(45.5 \%)\end{array}$ & $\begin{array}{c}14.1 \\
(105.0 \%)\end{array}$ \\
\hline 2 & $\begin{array}{c}167 \\
(19.2 \%)\end{array}$ & $\begin{array}{c}179 \\
(20.5 \%)\end{array}$ & 21.3 & 115.2 & $\begin{array}{c}3.6 \\
(26.4 \%)\end{array}$ & $\begin{array}{c}20.6 \\
(153.4 \%)\end{array}$ \\
\hline 3 & $\begin{array}{c}60 \\
(6.9 \%)\end{array}$ & $\begin{array}{c}83 \\
(9.6 \%)\end{array}$ & 28.6 & 243.3 & $\begin{array}{c}1.7 \\
(12.7 \%)\end{array}$ & $\begin{array}{c}20.3 \\
(150.8 \%)\end{array}$ \\
\hline
\end{tabular}

Mean from two separate experiments.

TABLE VII. Effect of PKE on Colony Formation of 5-FU Injected Mouse Bone Marrow Cells

\begin{tabular}{lrccc}
\hline \multirow{2}{*}{ Treatment } & \multirow{2}{*}{ Mice } & \multicolumn{2}{c}{ No. of colonies } & Ratio \\
\cline { 3 - 4 } & & Without PKE & With PKE & \\
\hline Control $\left(5 \times 10^{4}\right.$ cells $)$ & 8 & $60.3 \pm 1.4$ & $124.5 \pm 8.5$ & 2.07 \\
5-FU $\left(3 \times 10^{5}\right.$ cells $)$ & 11 & $34.0 \pm 4.6$ & $102.6 \pm 13.7$ & 3.02 \\
\hline
\end{tabular}

Mean \pm S.E.

\section{5-FU 投与マウス骨髄細胞のコロニー形成に対する PKE の作用}

5-FUを投与したマウスの骨䯣細胞を用いCFU-C の測定を行った。その結果 Table VII 亿示すように, 5-FU 非投与マウスの骨髄細胞に括いてはPKEによりコロニー数は約 2 倍に増加したのに対し，5-FU 投与マウスの 骨髄細胞では PKE の添加によりコロニー数の增加は約 3 倍と, 対照に比べょり高い増加率を示した.

Table I 飞示したように, PKE は CSF 存在下でマウス骨髄細胞による顆粒球一マクロファージ系のコロニー数 を増加させることから PKE 中に CPA が含まれていることが明らかになった. PKE によるコロニー增幅率は, CSF の濃度が高い領域では，一定であった (Table II). また， 2 種の CSF を用いた実験では，CSF の種類を変 えても, 形成されるコロニー組成化変化を与えず (Table III), 生成するコロニーの種類は共存する CSF の性質 に依存することが示唆された。これらのことから，CPA とCSF の作用点が異なることが推定され，次に考察す る細胞の一連の分化過程のうちの異なった段階に作用するとする考光を支持する.

PKE 添加培地で CSF を加えずに骨䯣細胞を preincubateすると, 総細胞数は減少するのに対し CFU-C 数 が増加する。一方, PKE を加えない場合には総細胞数, CFU-C 数ともに減少する (Table VI)ことから, PKE には CFU-C を特異的に維持する作用ととるに，増加させる作用があると考流られる。したがって，PKE は CFU-C より pre-CFU-C に働き，それを CSF 反応性である CFU-C にまで增殖・分化させる作用によりコロ 
ニー数を增加させていることが示晙された。

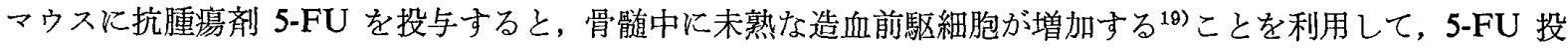
与マウスの骨䯣細胞について，PKE の作用を検討した結果，正常骨髄細胞を用いた場合に比べて 5-FU 投与マ ウスの骨髄細胞を用いた場合のほうがコロニー増幅率は高い值を示した (Table VII).このことはやはり，PKE が pre-CFU-C を増殖させる作用をもつことをららづけている。

また PKE 中の CPA 活性は $70^{\circ} \mathrm{C}, 30$ 分間の加熱処理で失活し，トリプシン感受性であることが明らかとな った (Table IV, V).

CPA についての関連する報告には，マウス骨髄性白血病細胞（WEHI-3）培養上清, 12) マウス骨䯣細胞長期培 養上清 ${ }^{13)}$ 及びヒト末梢血白血球の培養液 ${ }^{20)}$ に含まれる CPA がマウス骨髄細胞の CFU-C の維持, 増加作用をも つといら報告，マウス骨䯣性白血病細胞培養上清中に含まれる CPA は, CSF の標的細胞より未熟な造血前駆細 胞に対し作用している可能性を示唆した報告, ${ }^{12)}$ マウス骨髄細胞長期培養上清中の CPA ないことから, CFU-S と CFU-C の間の cell population に作用することを示唆した報告, ${ }^{13)}$ 熱安定性及びトリ プシン感受性についての報告211などある。この報告に拉いて著者等が存在を明らかにした腎臓抽出物中に含まれ るCPA についても，他の原料に由来するそれらの CPA の性質及び作用と一致する点が多く認められ，類似の 物質である可能性がある。

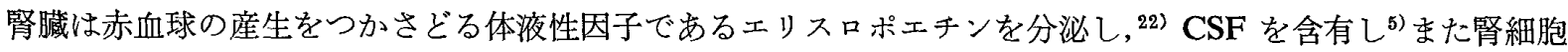
による in vitro での CSF 産生 ${ }^{23)}$ な造血に深く関与する蔵器の 1 つであることが知られている. 一方, ブタ循 環器系, 消化器系等がヒトのそれに類似していると言われている. ${ }^{24)}$ 既に報告されている他の CPA の多くが各 種細胞の培養液中に検出されているのに対し, 著者らは CPA を蔵器中に初めて見い出し, その蔵器が腎葴であ ることを考え合わせると，造血系に果たす腎臓の役割を考える上で興味深い.

\section{引用文献}

1) M. Paran, L. Sachs, J. Cell. Physiol., 72, 247 (1968).

2) G. Pigoli, A. Waheed, R. K. Shadduck, Blood, 59, 408 (1982).

3) R. W. Bolin, W. A. Robinson, J. Cell. Physiol., 92, 145 (1977).

4) K. Motoyoshi, F. Takaku, H. Mizoguchi, Y. Miura, Blood, 52, 1012 (1978).

5) J. W. Sheridan, E. R. Stanley, J. Cell. Physiol., 78, 451 (1971).

6) M. J. Cline, B. Rothman, D. W. Golde, J. Cell. Physiol., 84, 193 (1974).

7) T. Okabe, H. Nomura, N. Sato, N. Ohsawa, J. Cell. Physiol., 110, 43 (1982).

8) M.-C. Wu, R. A. Fisher, Biochemistry, 19, 3846 (1980).

9) K. Tsuneoka, M. Shikita, Cell. Struc. Func., 9, 67 (1984).

10) K. Tsuneoka, Y. Takagi, K. Hirashima, M. Shikita, Exp. Hemat., 6, 445 (1978).

11) S. Bol, N. Williams, J. Cell. Physiol., 102, 233 (1980).

12）梶ヶ谷保彦, 生田孝一郎, 小磯良孝, 船曳哲典, 松山秀介, 日本血液学会雑誌, 50,575 (1987).

13) H. Izumi, M. Tsurusawa, T. Miyanomae, K. Kumagai, K. J. Mori, Leuk. Res., 7, 155 (1983).

14) M. Tsurusawa, T. Miyanomae, H. Izumi, K. J. Mori, Leuk. Res., 7, 167 (1983).

15) S. Aizawa, I. Amaki, M. Tsurusawa, H. Tezuka, H. Izumi, K. J. Mori, ACTA Haematol. Jpn., 49, 19 (1986).

16）柏倉幾郎，早瀬幸敏，高木良成，日本薬学会第 105 年会講演要旨集，千葉，1986，p. 345.

17) 柏倉幾郎，早瀬幸俊，高木良成，薬誌，105, 42 (1985).

18) T. Suda, J. Suda, M. Ogawa, Proc. Natl. Acad. Sci. U.S.A., 80, 6689 (1983).

19) T. Nakahata, T. Akabane, Acta Haematol. Jpn., 47, 1764 (1984).

20) G. Wagemaker, M. F. Peters, Cell Tissue. Kinet., 11, 45 (1978).

21）上代淑人, 菊池吾郎, “続生化学実験講座 8 巻, 血液上,”第 1 版, 日本生化学会編, 東京化学同人, 東 京, 1987, pp. 31-35.

22) J. W. Fisher, Proc. Soc. Exp. Biol. Med., 173, 289 (1983).

23) T. R. Bradley, D. Metcalf, Aust. J. Exp. Biol. Med. Sci., 44, 287 (1966).

24）谷本義文, “血液学一七トと動物の接点一, ”清至書院, 東京, 1982, pp. 111-117. 